\title{
Effect of Saline Irrigation Water, Foliar Boron Fertilization and Forced Defoliation on the Sugar Beet Yield
}

\author{
Mahmoud, I. I. , A. A. Aboushal 1
}

\begin{abstract}
This experiment aimed to examine the effect of irrigation water salinity, foliar boron application and forced defoliation on the sugar beet growth and sugar yield as main product. Sugar beet plant (Beta vulgaris L.) was subjected to four levels of irrigation water salinity, three levels of foliar boron addition and three levels of forced defoliation. Split-split plot design was used for conducting the experiment. Four main plots were used for irrigation water treatment. Plant growth and sugar production were evaluated. The obtained data showed that the sugar beet crop is not only a salt tolerant but also needs the soluble salts (up to $6.2 \mathrm{dS} \mathrm{m}^{-1}$ ) to progress the yield where it promoted the average root yield and consequently the sugar yield of the two seasons by 27.4 and $24.5 \%$, respectively. Foliar boron fertilization level up to $0.2 \mu \mathrm{g} / \mathrm{g}$ was enough to increase the average root yield and consequently the sugar yield of the two seasons by 24.5 and $\mathbf{2 0 . 8 \%}$,respectively. Sugar yield was promoted significantly in spite of the inhibition effect of boron on the sucrose concentration in the tuber's tissues. The forced defoliation considerably inhibited the yield of whole plant, roots, shoots and sugar.
\end{abstract}

\section{INTRODUCTION}

Improving sugar beet yield and quality are the main goals of the governmental policy to increase sugar production in order to gradually cover the gap between sugar consumption and production.

Low irrigation water quality inevitably leads to the salinization of soils and waters. Worldwide, crop production is limited by the effects of salinity on about $50 \%$ of the irrigated land area. (Harrison, 1997). The potential for crop productivity under such conditions is dependent upon the plant response to osmotic stress and to the relative toxicity of some ions such as $\mathrm{Na}^{+}$and $\mathrm{Cl}^{-}$. In most cases, a reduction in the yield was normally associated with an accumulation of soluble salts in plant tissues (Flowers and Hall, 1978; Greenway and Munns, 1980).

Boron is an essential micronutrient for plants. Some plants are more susceptible to boron deficiency and toxicity than others. Foliar boron improved seed set, seed yield, and seed quality of Alfalfa (Christos Dordas,
2006). Boron as micro-nutrient is very important to have healthy plants and consequently, by high root yield, and sugar content. Boron deficiency was the cause of heart rot and dry rot of sugar beet and added B (Brandenburg, 1931). There were no positive yield effects observed in Missouri with split foliar applications of B at rates of either 0.56 or $1.12 \mathrm{~kg} \mathrm{ha}^{-1}$ applied (Reinbott and Blevins, 1995). Similarly, B applied at rates up to $3.3 \mathrm{~kg} \mathrm{ha}^{-1}$ in Virginia had no effect on soybean yield over $6 \mathrm{yr}$ (Martens et al., 1974). The forced defoliation tested herein as a source of animal feeding was tested to distinguish the ability of the sugar beet crop to share in the overcoming of the forage crops deficient.

The trend in production of sugar plants differs between the types. Sugar beet area and production decreased during the last decade by almost $15 \%$. The decline in beet area was partly compensated by an overall increase in beet yield of $17 \%$. However, in order to achieve a higher yield, the plant has to absorb more nutrients. In other words, the demand for vertical increase in crop output can only be met by simultaneous increase in nutrient supply to the plants. As the tuber crops and sugar beet have a relatively poor root system when compared to cereals, this restrictive the soil volume, which can be exploited and thus requires a much higher nutrient elements concentration in soil solution to meet the demand for the crop, (EI-Maghraby et al., 1997).

\section{MATERIALS AND METHODS}

Monogerm sugar beet (Plino. Var) seeds were cultivated at a farm in Kafr Eldawar area for two seasons (November 2004 and November 2005) and were harvested at 190 days age. Before planting, Superphosphate was added at the rate of $100 \mathrm{mg}$ per $\mathrm{kg}$ of soil. Nitrogen was added in the form of ammonium nitrate at the rate of $100 \mathrm{mg} \mathrm{N}$ per $\mathrm{kg}$ of soil. Half of nitrogen was added after 15 days from planting and the second half was 30 days after planting. Potassium was added after planting as potassium sulfate at the rate of $100 \mathrm{mg} \mathrm{K}$ per $\mathrm{kg}$ of soil. The used soil was chemically analyzed for $\mathrm{pH}, \mathrm{EC}$, soluble cations and anions in the

\footnotetext{
${ }^{1}$ Soil Salinity Dept., Soil, Water and Environment Res. Inst., Agric. Res. Center, Giza, Egypt

Alexandria July 24, 2007, Accepted September 17, 2007
} 
Table 1a. Chemical properties of the used soil for first and second seasons.

\begin{tabular}{|c|c|c|c|c|c|c|c|c|c|c|}
\hline \multirow[t]{2}{*}{ Season } & \multirow{2}{*}{$\begin{array}{c}\text { EC } \\
\text { dS m }{ }^{-1}\end{array}$} & \multirow[t]{2}{*}{$\mathbf{p H}$} & \multicolumn{4}{|c|}{ Cations (meq/L) } & \multicolumn{4}{|c|}{ Anions (meq/L) } \\
\hline & & & $\mathrm{Ca}^{2+}$ & $\mathrm{Mg}^{2+}$ & $\mathbf{N a}^{+}$ & $\mathbf{K}^{+}$ & $\mathrm{HCO}_{3}^{-}$ & $\mathrm{CO}_{3}{ }^{2-}$ & $\mathrm{Cl}^{-}$ & $\mathrm{SO}_{4}{ }^{2-}$ \\
\hline $1 \mathrm{st}$ & 3.6 & 7.8 & 9.6 & 6.2 & 19.1 & 1.0 & 2.4 & n.d. & 31.1 & 2.2 \\
\hline 2nd & 3.8 & 7.8 & 10.0 & 6.0 & 21.0 & 1.7 & 3.0 & 0.2 & 32.0 & 2.2 \\
\hline
\end{tabular}

Table 1b. Average values of salinity $\left(\mathrm{dS} \mathrm{m}^{-1}\right)$ of used waters and soil before and after cultivation.

\begin{tabular}{|c|c|c|}
\hline Treatment & 1st season & 2nd season \\
\hline & \multicolumn{2}{|c|}{ Water salinity, $\mathrm{dS} \mathrm{m}^{-1}$} \\
\hline Irrigation water & 4.7 & 4.8 \\
\hline \multirow[t]{4}{*}{ Drainage water } & 9.4 & 9.1 \\
\hline & \multicolumn{2}{|c|}{ Soil salinity before cultivation, $\mathrm{dS}^{-1}$} \\
\hline & 3.6 & 3.8 \\
\hline & \multicolumn{2}{|c|}{ Soil salinity after cultivation, $\mathrm{dS} \mathrm{m}^{-1}$} \\
\hline S1 & 5.7 & 4.1 \\
\hline S2 & 6.1 & 4.9 \\
\hline S3 & 6.2 & 5.6 \\
\hline S4 & 6.6 & 6.5 \\
\hline
\end{tabular}

soil paste (Table 1a) according to standard methods edited by Black (1965).

\section{Experimental design:}

108 plots each $10.5 \mathrm{~m}^{2}$ were used in conducting the experiment as a split-split plot design using 3 replicates with the following treatments:

1- Irrigation water salinity of 4.7, 6.2, 7.9 and $9.4 \mathrm{dS} \mathrm{m}^{-1}$ referred here as S1, S2, S3 and S4, respectively, where S1 and S4 represent the salinity of irrigation and drainage waters, from which the other two salinity levels were obtained as mixtures.

2- Foliar application of boron: $0,0.1$ and $0.2 \mathrm{~kg} \mathrm{~B} \mathrm{/}$ faddan referred here as B0, B1 and B2. Boric acid (as a source of boron) was dissolved in distilled water as a stock solution for preparing the needed solution concentrations.

3- $0,20,40 \%$ of leaves will referred after as D0, D1 and D2 were forcely defoliated 30 days before harvesting.

Soil samples before and after agriculture, irrigation water and drain water were analyzed for their salinity to indicate the effect of saline water used on the soil salinity (Table $1 \mathrm{~b}$ ).

The yield was harvested at 190 days age. Whole plants, roots and shoots weights were measured. Data are shown in Tables 2 and 3 for the first and second season, respectively. The tuber yield of each treatment was sent to the factory for sugar extracting to determine sugar percentage (Le-Docte, 1927).

The data of sugar yield of all treatments are shown in Tables 2 and 3. The data of whole plants, shoots, roots and sugar yield were computed and statistically analyzed for testing the significance of the tested factors and the possible interaction between them.

\section{RESULTS AND DISCUSSION}

The used soil is classified as a saline soil before cultivation (3.6 and $3.8 \mathrm{dS} \mathrm{m}^{-1}$ for the first and second seasons, respectively). The soil salinity increased according to the salinity of irrigation water as shown in Table $1 \mathrm{~b}$ after both seasons. The high expected soil salinity after harvesting did not occur, this may be due to a partial leaching of salts by rains fall 2-3 weeks before harvesting. The effect of boron fertilization and forced defoliation on the fresh weight of the whole plant, roots, shoots and on sugar yield for the first and second seasons are presented in Tables 2 and 3, respectively.

The results obtained showed that the second level of water salinity ( $\mathrm{S} 2=6.2 \mathrm{dS} \mathrm{m}^{-1}$ ) was the most effective level, where promoted the whole plant weight $44.1 \%$ followed by S3, S4 then S1 (Table 2 and Figure 1). Second season showed similar trend for the effect of irrigation with saline water on the whole plant weight (Table 3 and Figure 1) where S2 increased the root yield $32.8 \%$.

Both seasons cleared a significant effect of salinity on the whole plant weight. The results obtained for the 
root yield as affected by irrigation water salinity showed also, that the second level of irrigation water salinity (S2) was the most effective level where raised the yield $27.3 \%$ followed by S3, S1 then S4 for the first season and for the second season, S2 raised the yield $28.1 \%$. The results of the second season were similar and close to those of first season except the effect of the highest level which was negative and decreased by $1.8 \%$ for the first season while it increased the root yield $7.4 \%$. The effect of salinity of the irrigation water on the tuber's yield was significant for both seasons. Shoot yield was significantly affected by salinity level of irrigation water and showed the same manner of the whole plant. The sugar yield was obviously affected significantly for both seasons by the salinity level of the irrigation water. The second level of irrigation water salinity (S2) was the most effective level where it increased the sugar yield $23.1 \%$ for the first season and $24.7 \%$ for the second season while the highest level of irrigation water salinity (S4) showed a negative effect through decreasing the sugar yield $13.6 \%$ and $7.2 \%$ for the first and second seasons, respectively.

The data of sucrose percentage manifested the significant negative effect of irrigation water salinity on sucrose concentration in tuber tissues. In spite of the negative effect of salinity on the sucrose concentration in sugar beet roots, the sugar yield promoted due to the higher positive effect on the root yield especially with S2. The results obtained cleared a disagreement with the findings of Flowers and Hall (1978), and Greenway and Munns (1980), where they announced the negative effect of salinity on the yield crop was due to the osmotic stress and to the relative toxicity of sodium and chloride ions. This disagreement may be due to plants used where sugar beet plant has a relatively small root system when compared to cereals and legumes which have higher ability to absorb nutrients from soil. It has been reported that saline water is rich in essential nutrients to supply tuber with the enough of nutrients to meet the demand of the crop (EI-Maghraby et al., 1997).

Table 2. Effect of irrigation water salinity, boron fertilization and forced defoliation on the yield of whole plant, roots, shoots and sugar (ton/fad.) for first season.

\begin{tabular}{|c|c|c|c|c|c|}
\hline \multirow[t]{2}{*}{ Treatment } & Whole plant & Root & Shoot & Sugar & \multirow{2}{*}{$\begin{array}{c}\text { Sucrose } \\
\%\end{array}$} \\
\hline & \multicolumn{4}{|c|}{ Ton / faddan } & \\
\hline $\mathrm{S} 1$ & $28.52 \mathrm{c}$ & $21.33 \mathrm{c}$ & $7.19 \mathrm{~d}$ & $3.89 \mathrm{c}$ & $18.22 \mathrm{a}$ \\
\hline $\mathrm{S} 2$ & $41.09 \mathrm{a}$ & $27.14 \mathrm{a}$ & $13.95 \mathrm{a}$ & $4.79 \mathrm{a}$ & $17.72 \mathrm{~b}$ \\
\hline $\mathrm{S} 3$ & $34.05 \mathrm{~b}$ & $22.83 \mathrm{~b}$ & $11.22 \mathrm{c}$ & $4.00 \mathrm{~b}$ & $17.52 \mathrm{c}$ \\
\hline $\mathrm{S} 4$ & $33.86 \mathrm{~b}$ & $20.94 \mathrm{~d}$ & $12.92 \mathrm{~b}$ & $3.36 \mathrm{~d}$ & $16.07 \mathrm{~d}$ \\
\hline L.S.D. $5 \%$ & 0.430 & 0.340 & 0.152 & 0.070 & 0.920 \\
\hline B0 & $30.43 \mathrm{c}$ & $19.85 \mathrm{c}$ & $10.57 \mathrm{c}$ & $3.53 \mathrm{c}$ & $17.74 \mathrm{a}$ \\
\hline B1 & $35.97 \mathrm{~b}$ & $23.97 \mathrm{~b}$ & $12.00 \mathrm{a}$ & $4.11 \mathrm{~b}$ & $17.09 \mathrm{c}$ \\
\hline $\mathrm{B} 2$ & $36.74 \mathrm{a}$ & $25.36 \mathrm{a}$ & $11.34 \mathrm{~b}$ & $4.40 \mathrm{a}$ & $17.32 \mathrm{~b}$ \\
\hline L.S.D. $5 \%$ & 0.208 & 0.198 & 0.120 & 0.320 & 0.024 \\
\hline D0 & $37.27 \mathrm{a}$ & $24.74 \mathrm{a}$ & $12.53 \mathrm{a}$ & $4.28 \mathrm{a}$ & $17.36 \mathrm{~b}$ \\
\hline D1 & $31.29 \mathrm{c}$ & $21.21 \mathrm{c}$ & $10.07 \mathrm{c}$ & $3.72 \mathrm{c}$ & $17.49 \mathrm{a}$ \\
\hline D2 & $34.54 \mathrm{~b}$ & $23.23 \mathrm{~b}$ & $11.31 \mathrm{~b}$ & $4.03 \mathrm{~b}$ & $17.29 \mathrm{c}$ \\
\hline L.S.D. 5\% & 0.172 & 0.159 & 0.093 & 0.027 & 0.016 \\
\hline Mean & 34.38 & 23.06 & 11.32 & 4.01 & 17.38 \\
\hline L.S.D. $5 \%(\mathrm{~S} * \mathrm{~B})$ & 1.251 & 1.888 & 0.722 & 0.190 & 0.134 \\
\hline L.S.D. 5\% (S*D) & 1.033 & 0.956 & 0.561 & 0.136 & 0.090 \\
\hline L.S.D. $5 \%(\mathrm{~B} * \mathrm{D})$ & 0.894 & 0.828 & 0.486 & 0.135 & 0.078 \\
\hline L.S.D. 5\% $(\mathrm{S} * \mathrm{~B} * \mathrm{D})$ & 1.789 & 1.655 & 0.972 & 0.270 & 0.156 \\
\hline
\end{tabular}




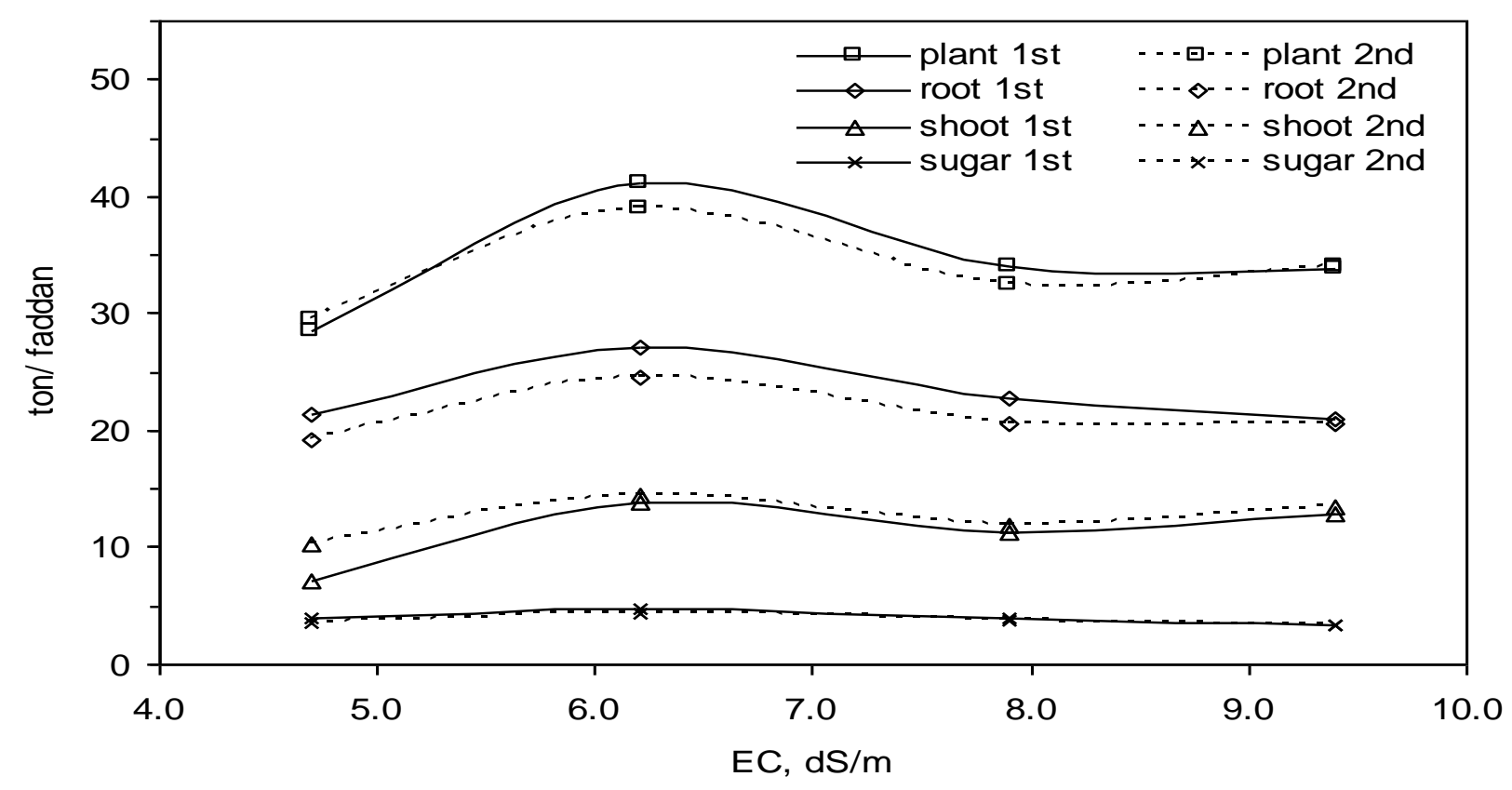

Fig.1. Relationship between irrigation water salinity and plant, root, shoot and sugar yield.

Table 3. Effect of irrigation water salinity, boron fertilization and forced defoliation on the yield of whole plant, roots, shoots and sugar (ton/fad.) for 2 nd season.

\begin{tabular}{cccccc}
\hline Treatment & Whole plant & Root & Shoot & Sugar & Sucrose \\
\cline { 2 - 5 } & \multicolumn{2}{c}{ Ton / faddan } \\
\hline S1 & $29.39 \mathrm{~d}$ & $19.12 \mathrm{c}$ & $10.27 \mathrm{~d}$ & $3.48 \mathrm{c}$ & $18.58 \mathrm{a}$ \\
S2 & $39.03 \mathrm{a}$ & $24.49 \mathrm{a}$ & $14.54 \mathrm{a}$ & $3.92 \mathrm{a}$ & $17.69 \mathrm{~b}$ \\
S3 & $32.40 \mathrm{c}$ & $20.62 \mathrm{~b}$ & $11.77 \mathrm{c}$ & $3.58 \mathrm{~b}$ & $17.48 \mathrm{c}$ \\
S4 & $34.05 \mathrm{~b}$ & $20.62 \mathrm{~b}$ & $13.43 \mathrm{~b}$ & $3.23 \mathrm{~d}$ & $16.04 \mathrm{~d}$ \\
\hline B.S.D. 5\% & 0.242 & 0.232 & 0.056 & 0.018 & 0.037 \\
\hline B1 & $30.46 \mathrm{c}$ & $19.56 \mathrm{c}$ & $10.90 \mathrm{c}$ & $3.55 \mathrm{c}$ & $17.70 \mathrm{a}$ \\
B2 & $35.97 \mathrm{a}$ & $21.84 \mathrm{~b}$ & $14.13 \mathrm{a}$ & $3.80 \mathrm{~b}$ & $17.05 \mathrm{c}$ \\
\hline L.S.D. 5\% & $34.73 \mathrm{~b}$ & $22.25 \mathrm{a}$ & $12.47 \mathrm{~b}$ & $3.95 \mathrm{a}$ & $17.29 \mathrm{~b}$ \\
\hline D0 & 0.112 & 0.121 & 0.096 & 0.008 & 0.010 \\
D1 & $36.44 \mathrm{a}$ & $23.79 \mathrm{a}$ & $12.65 \mathrm{~b}$ & $4.20 \mathrm{a}$ & $17.33 \mathrm{~b}$ \\
D2 & $31.47 \mathrm{c}$ & $20.50 \mathrm{~b}$ & $10.96 \mathrm{c}$ & $3.66 \mathrm{~b}$ & $17.46 \mathrm{a}$ \\
\hline L.S.D. 5\% & $33.24 \mathrm{~b}$ & $19.35 \mathrm{c}$ & $13.90 \mathrm{a}$ & $3.42 \mathrm{c}$ & $17.26 \mathrm{c}$ \\
\hline Mean & 0.076 & 0.089 & 0.096 & 0.006 & 0.006 \\
L.S.D. 5\% (S*B) & 33.72 & 21.21 & 12.50 & 3.55 & 17.45 \\
L.S.D. 5\% (S*D) & 0.212 & 0.728 & 0.577 & 0.164 & 0.060 \\
L.S.D. 5\% (B*D) & 0.431 & 0.532 & 0.381 & 0.040 & 0.040 \\
L.S.D. 5\% (S*B*D) & 0.373 & 0.461 & 0.330 & 0.035 & 0.035 \\
\hline
\end{tabular}

The data in Tables 2 and 3 and Figure 2 showed that boron fertilization magnified significantly the whole plant weight $18.2 \%$ with the addition level $0.1 \mu \mathrm{g} / \mathrm{g}$ for the first season. The higher level of $\mathrm{B}$ addition showed higher positive effect than the first level on its effect on the whole plant weight. Similar effect was noticed clearly in the second season. Boron fertilization at the first season increased sugar beet tuber weight by 20.8 and $27.8 \%$ for the 0.1 and $0.2 \mu \mathrm{g} / \mathrm{g}$, respectively. Although, for the second season sugar beet tuber weight 


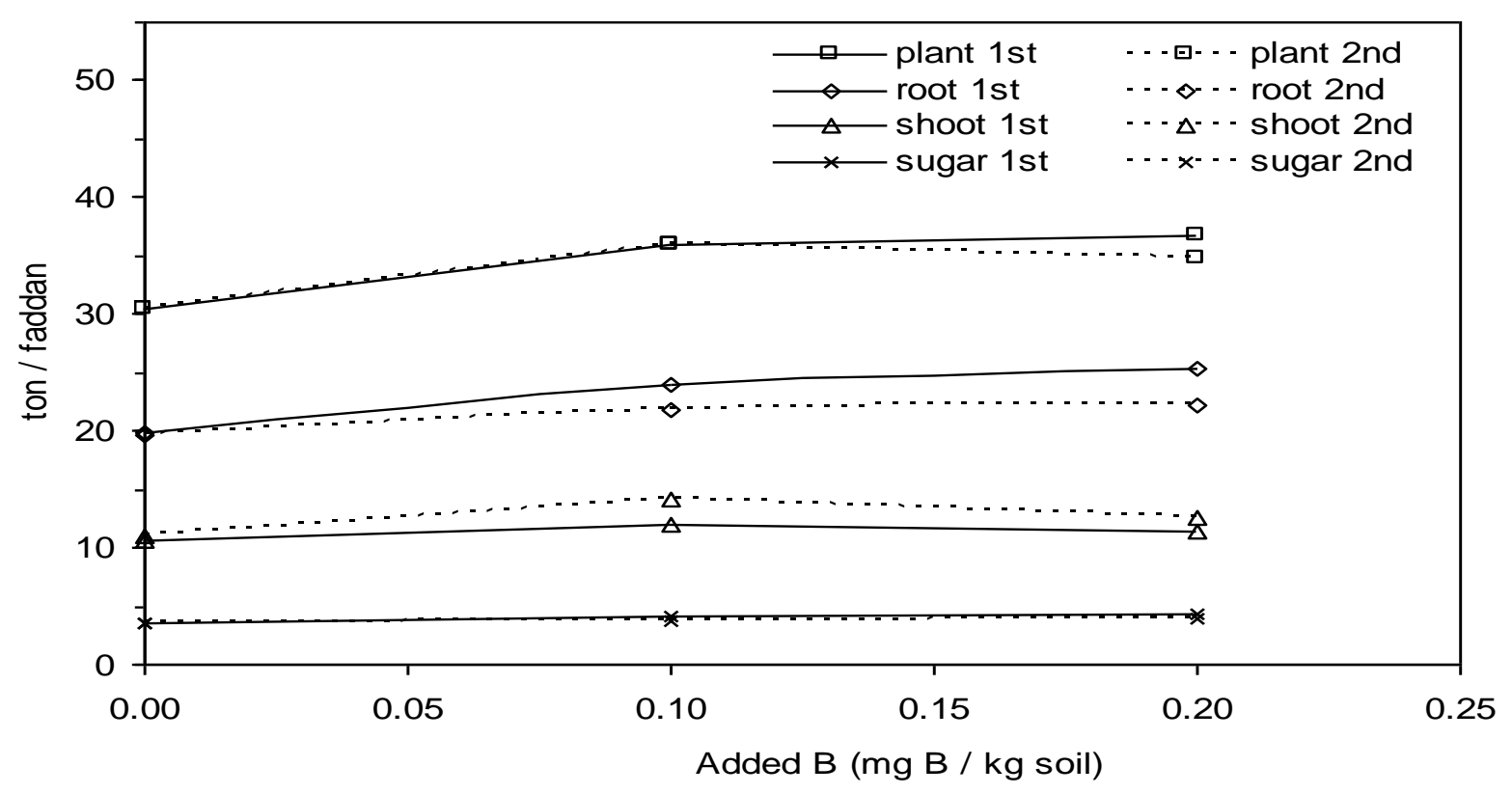

Fig.2. Relationship between boron fertilization rate and plant, root, shoot and sugar yield.

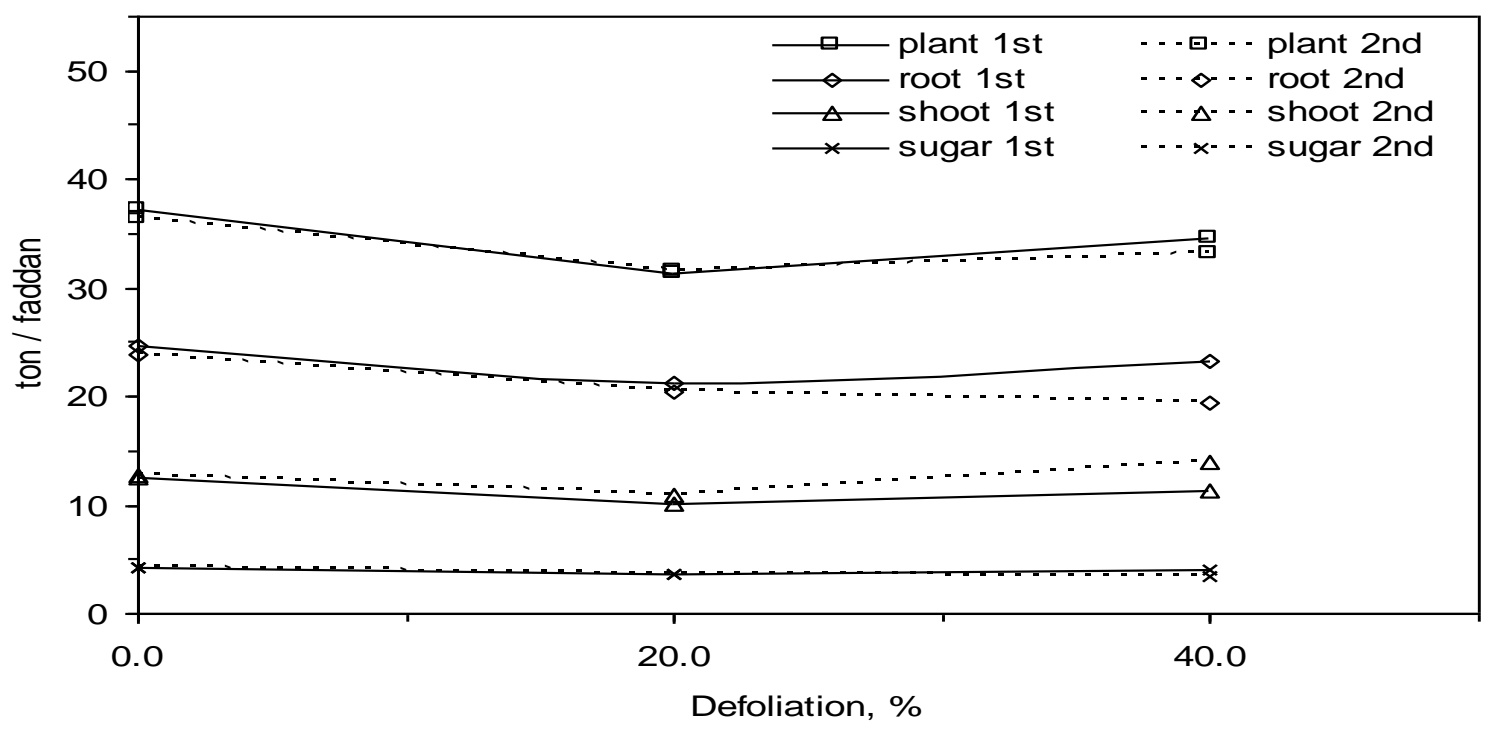

Fig. 3. Relationship between defoliation percentage and plant, root, shoot and sugar yield.

were raised 11.6 and $13.8 \%$ only for the 0.1 and $0.2 \mu \mathrm{g}$ $/ \mathrm{g}$, respectively, the data showed the same significant positive effect and same trend for first season. The data of shoot yield pointed out positive significant effect of added boron for both season. The data of sugar yield demonstrated the positive significant effect of boron fertilization, although the significant negative effect of added boron on the sucrose concentration for both seasons. This indicates the net boron effect was positive on the sugar yield as a main goal.

The data in Tables 2 and 3 and Figure 3 illustrated the inhibition effect of the forced defoliation on the yield of whole plants, shoots, roots and sugar yield was significantly, especially with lower percent of defoliation (Figure 3). Higher defoliation did not cause more inhibition but sometimes raised the measured parameter slightly keeping the negative effect on the 
plant, root and sugar yield. Higher defoliation may be pushed plant to accelerate the formation and growth of new leaves to substitute the old leaves and encourage the root to absorb more nutrients needed for this action. In general, defoliation inhibited sucrose percentage and beet yield significantly which resulted in lower sugar yield as a main goal.

The interactions between the studied factors on all measured parameters were significant as shown in Tables 2 and 3. The data of the sugar yield, as the main goal are listed in Table 4 according to the interaction between the studied factors.

Table 4. Effect of interaction between the studied factors on sugar yield.

\begin{tabular}{cccccc}
\hline Treatment & S1 & S2 & S3 & S4 & Mean \\
\hline B0 & 3.18 & 4.64 & 3.51 & 2.84 & 3.89 \\
B1 & 4.10 & 4.53 & 3.29 & 3.90 & \\
B2 & 3.90 & 4.66 & 4.76 & 3.39 & \\
\hline \multicolumn{1}{c}{ S1 } & S2 & S3 & S4 & \\
\hline D0 & 3.76 & 4.65 & 4.31 & 4.25 & \\
D1 & 3.73 & 4.31 & 3.51 & 3.22 & \\
D2 & 3.68 & 4.86 & 3.72 & 2.65 & \\
\hline D0 & B0 & B1 & B2 & & \\
D1 & 3.78 & 4.15 & 4.80 & & \\
D2 & 3.28 & 3.52 & 4.00 & & \\
\hline
\end{tabular}

The results of interaction between irrigation water salinity and foliar boron fertilization rate cleared the net positive effect of both factors was at salinity level 6.2 $\mathrm{dS} \mathrm{m^{-1 }}$ and boron $0.2 \mu \mathrm{g} / \mathrm{g}$, where the sugar yield enhanced $20 \%$ of the overall mean. The interaction between irrigation water salinity and defoliation decreased sugar yield with the highest level of salinity and decreased the sugar yield $32 \%$ of the overall. In spite of the negative effect of defoliation, the positive effect of salinity up to $6.2 \mathrm{dS} \mathrm{m}^{-1}$ raised the sugar yield
$24.8 \%$. The interaction between boron fertilization rate and defoliation on the sugar yield showed relative equality of the positive effect of boron and the negative effect of defoliation where the sugar yield was inhibited only $4 \%$ at the two highest levels of boron and defoliation.

\section{REFERENCES}

Black, C.A. (1965). Methods of soil analysis. American Soc. Inc. Pub., Madison, Wisconsin, USA.

Brandenburg. E. (1931). Die Herz-und trokenfaule der Ruben als Bormangcler Schienung. Phytopathology, 3, 449-517.

Christos Dordas (2006). Foliar boron application improves seed set, seed yield, and seed quality of alfalfa. Agron J. 98:907-913.

EI-Maghraby, S., Mona M. Shehata and Yussreya H. Tawfik (1997). Effect of soil and foliar application of nitrogen and potassium fertilization on sugar beet. Adv. Agric. Res. 2:161-175.

Flowers, J. J.; and J. L. Hall (1978). Salt tolerance in the halophyte. Suaed mariuma (L.) Dum. : The influence of the salinity of the culture solution on the content of various organic compounds. Ann. Bot. 42:1057-1063.

Greenway, H. and R. Munns. (1980). Mechanisms of salt tolerance in non-halophytes. Ann. Rev. Plant. Physiol. 31:149 - 190 .

Harrison RM. (1997). Understanding Our Environment. An Introduction to Environmental Chemistry and Pollution. UK: University of Birmingham.;Ch3.

Le-Docte, A. (1927). Commercial determination of sugar beet in the beet root using Sachr-Le- Docte process. Int. Sug. J. 29:488-492.

Martens, D.C., M.T. Carter, and G.D. Jones. (1974). Response of soybeans following six annual applications of various levels of boron, copper, and zinc. Agron. J. 66:82-84.

Reinbott, T.M., and D.G. Blevins. (1995). Response of soybean to foliar-applied boron and magnesium and soilapplied boron. J. Plant Nutr. 18:179-200. 


\section{الملخص العربي}

\section{تأثير ملوحة مياه الرى والتسميد الورقى بالبورون ونزع الأوراق على محصول بنجر السكر النامى فى الأرض الجيرية. \\ إبراهيم إسماعيل محمود ، أممد عبد الرازق أبوشال}

حيث زاد مـن عصول الجـذور وبالتـالى عصصول السكر بنسبة 27.4 و 24.5\% على الترتيب كنسبة متوسطه للموسمين.

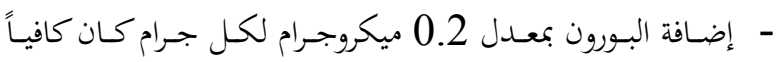

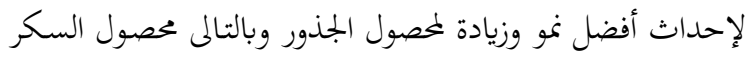
بنسبة 24.5 و 20.8\% على الترتيب كنسبة متوسطه للموسمين. هذا وقد زاد محصول السكر على الرغم من التأثير السلبى للبورون التبان على تركيز السكروز فن أنسجة الدرنات.

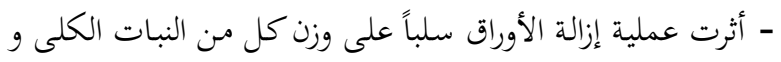

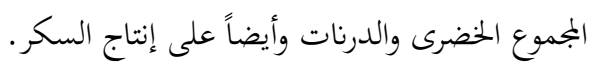

إستهدفت الدراسة إختبار تأثير ملوحة مياه الرى والتسميد الورقى

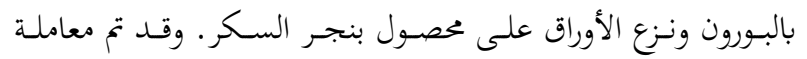

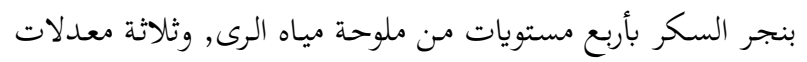

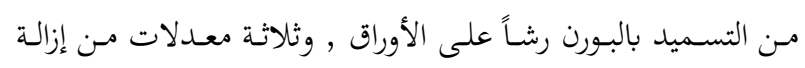

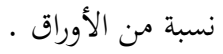
تم تقييم معدلات النمو و كذا إنتاج السكر وقد أوضحت النتائج ما يلى: - نبات بنجر السكر ليس فقط متحمل للملوحة ولكنه يحتاج إلى

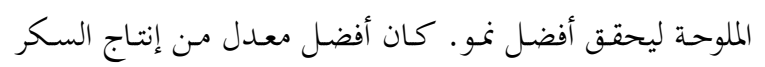

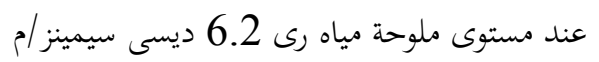

